\title{
Industrial orange waste as organic fertilizer in durum wheat
}

\author{
Rosalena Tuttobene ${ }^{1}$, Giovanni Avola ${ }^{2}$, Fabio Gresta $^{1 *}$, Valerio AbBate ${ }^{1}$ \\ ${ }^{1}$ Dipartimento di Scienze Agronomiche, Agrochimiche e delle Produzioni Animali - sezione Scienze Agronomiche, Università di Catania, Via Valdisavoia, \\ 595123 Catania, Italy \\ ${ }^{2}$ CNR - Istituto per i Sistemi Agricoli e Forestali del Mediterraneo (ISAFOM) - sezione di Catania, Stradale V. Lancia, Blocco Palma I, zona industriale, \\ 95121 Catania, Italy
}

(Accepted 29 April 2009)

\begin{abstract}
Nowadays agro-industrial waste induces increasing problems due to the high economic cost and heavy environmental impact of disposal. By contrast, its potential re-use as organic fertilizer could represent a sustainable approach to recycling nutrients and reintegrating organic matter into soil. Such recycling should be particularly beneficial in Mediterranean areas because there is a progressive loss of soil fertility. To assess the possible re-use of industrial citrus waste as organic fertilizer, a two-year research project was carried out to study the effects of dried orange waste on the growth and production of durum wheat (Triticum durum Desf.). Two dried orange waste doses of 4 and $8 \mathrm{~kg} / \mathrm{m}^{2}$ were compared with conventional mineral fertilization, of $80 \mathrm{~kg} / \mathrm{ha}^{2}$ of nitrogen, and with a control without fertilization in the first year. During the second year, the residual effects of the past year's fertilization and two-year application of the orange waste doses and mineral fertilization on duration of biological cycle, grain yield, leaf area index, above-ground biomass and crop growth rate were studied. Our results show that organic fertilization gave similar wheat yields to the mineral fertilization, averaging at 3.63 t/ha. Organic fertilization promoted crop growth much more than mineral fertilization, by up to $+400 \%$. However, at the highest dose repeated organic fertilization induced a severe depressive effect on crop establishment. It indeed gave the lowest values for leaf area index of 0.6 , biomass of $222 \mathrm{~g} / \mathrm{m}^{2} \mathrm{dry}$ weight and crop growth rate of $2.5 \mathrm{~g} \mathrm{~m}^{-2} \mathrm{~d}^{-1}$ at the heading stage, and a $50 \%$ decrease in wheat grain yield. In both years, the lowest dose of orange waste produced maximum agronomic efficiency. We conclude that an appropriate use of dried orange waste as fertilizer can partially solve environmental problems related to the citrus fruit processing industry, and represents a low cost organic matter source for Mediterranean soil with poor fertility.
\end{abstract}

industrial orange waste / organic soil fertilizer / durum wheat / growth / yield

\section{INTRODUCTION}

In the last ten years, increasing attention has been paid to the reduction of industrial waste, resource conservation and by-product utilization, making 'waste' a resource to be utilized and not just discarded. In areas where citrus orchards are the prevalent crop, one of the most important agro-industrial activities is citrus-fruit processing, which produces a great amount of a mixture of pulp (30-35\%), peel (60-65\%), membrane and seed $(0-10 \%)$ waste. In Italy, citrus waste has been estimated at from 350000 to $450000 \mathrm{t}$ per year (Fisichella, 2004). Nowadays, in most industrialized countries, it is partially used for energy recovery (Ingram and Doran, 1995), production of flavor and fragrance enhancers in beverages, foods and household cleaning supplies (Braddock, 1999; Gentry et al., 2001), and as livestock feed (Wagner et al. 1983).

\footnotetext{
* Corresponding author: fgresta@unict.it
}

Nevertheless, in less industrialized areas, large quantities of orange waste are simply left to rot in the fields, with serious environmental consequences. Re-using it is hindered by the complex interaction of integrating it into agricultural systems, economics, logistics and organizational aspects, environmental regulations, and farmer acceptance (Merillot, 1998). Moreover, its agricultural use is certainly impeded by limited knowledge and little research on its composition (Van Heerden, 2002), and its effect on soil characteristics and crop performance (Correia Guerrero et al., 1995; Belligno et al., 2005).

Initial results using orange waste in agriculture as a soil conditioner or organic fertilizer have proven positive for the physical and chemical characteristics of the soil (Intrigliolo et al., 2005). In orange orchards, the long-term application of dry orange waste as an organic fertilizer produced yields similar to mineral fertilizers (Intrigliolo et al., 2005). By contrast, the amount of waste applied to arable soils needs better 
defining according to crop requirements and soil conditions (Correia Guerrero et al., 1995; Belligno et al., 2005; Abbate et al., 2008). To identify the effective and valuable re-use of citrus agro-industrial waste as organic fertilizer, this research studied the direct and residual effects of increasing doses of industrial dried orange waste on the growth and productivity of durum wheat (Triticum durum Desf.).

\section{MATERIALS AND METHODS}

The research was conducted over a two-year period (20012003) on durum wheat, $\mathrm{cv}$ 'Mongibello', sowed in $0.5-\mathrm{m}^{3}$ $(1 \times 1 \times 0.50)$ lysimetric tubs, filled with a sandy sub-alkaline soil, totally lacking limestone and organic carbon. Twelve tubs were arranged in a randomized block design with three replications. In the first year, the following treatments were applied: unconditioned soil (A - control); $4 \mathrm{~kg} \mathrm{~m}^{-2}$ orange waste (B), $8 \mathrm{~kg} \mathrm{~m}^{-2}$ orange waste (C) and nitrogen mineral fertilization (D $-80 \mathrm{~kg} \mathrm{ha}^{-1}$ total nitrogen, $50 \%$ of which was supplied at sowing as ammonia nitrogen and 50\% nitric nitrogen supplied during the stem extension stage).

In the second year, the following treatments were applied: unconditioned control $\left(A+0=A_{1}\right)$; unconditioned soil which was supplied in the 1st year of experimentation with $4 \mathrm{~kg} \mathrm{~m}^{-2}$ $\left(\mathrm{B}+0=\mathrm{B}_{1}\right)$ and $8 \mathrm{~kg} \mathrm{~m}^{-2}\left(\mathrm{C}+0=\mathrm{C}_{1}\right)$, repeating the soil amendment with $4 \mathrm{~kg} \mathrm{~m}^{-2}\left(\mathrm{~B}+4=\mathrm{B}_{2}\right)$ and $8 \mathrm{~kg} \mathrm{~m}^{-2}(\mathrm{C}+8=$ $\mathrm{C}_{2}$ ), and repeating mineral fertilization $\left(\mathrm{D}+80 \mathrm{~kg} \mathrm{~N}=\mathrm{D}_{1}\right)$.

The orange waste in the two-year trial was previously airdried for seven months to a humidity of $30-35 \%$. Orange waste is acidic ( $\mathrm{pH} 4)$, and rich in Total Organic Carbon (46\%), nitrogen $(14.5 \%)$ and $\mathrm{Ca}^{++}(8.5 \%)$, which is eight-fold higher than the other cations $\left(\mathrm{K}^{+}\right.$and $\left.\mathrm{Mg}^{++}\right)$. The dried orange waste was buried in the first $20 \mathrm{~cm}$ of soil one day before sowing. Sowing was carried out on December 14th 2001 and December 28th 2002, using 400 germinating kernels per $\mathrm{m}^{-2}$ of soil. The experimental plot $\left(0.5 \mathrm{~m}^{2}\right)$ consisted of 4 rows $0.80 \mathrm{~m}$ long ( $0.20 \mathrm{~m}$ between rows).

At emergence and at the late ripening stage, the number of plants and heads was recorded. All the plants in $0.30 \mathrm{~m}$ of one row (about 24 plants or 36 culms) for each lysimetric tub in 3 replicates were sampled in 3 successive phenological phases (tillering, heading and early milk ripening), cutting them at ground level. Leaf area (area measurement system, Delta $\mathrm{T}$ Devices Ltd., Burwell, Cambridge, England) and dry weight (by drying in a forced-air oven at $105^{\circ} \mathrm{C}$ ) were measured. Leaf Area Index (LAI ) and Crop Growth Rate $\mathrm{g} \mathrm{m}^{-2} \mathrm{~d}^{-2}$ (CGR) were calculated.

At full maturity, yield and its components (number of heads $\mathrm{m}^{-2}$, kernel head ${ }^{-1}$ and seed weight) were also determined for all the plants in the two internal rows; the Harvest Index (HI) and Agronomic Efficiency Index (AE) of the dried orange waste doses were calculated with the following formulas:

$\mathrm{HI}=\mathrm{Ky} / \mathrm{B}$ where $\mathrm{Ky}$ is the kernel yield and $\mathrm{B}$ the total biomass yield;

$A E=\left(Y_{p x}-Y_{p 0}\right) / p_{x}$ where $Y$ represents kernel production, and $\mathrm{p}$ the dried orange waste dose in treatments 0 and $\mathrm{x}$.
The crop parameter data were subjected to analysis of variance (ANOVA), the means being separated by Least Significant Difference (LSD) if the F-test was significant at $P \leq$ 0.05 . Analyses were performed separately for all the samples of each harvest, since sampling was not an experimental factor. Before performing ANOVA, biomass and leaf area data were subjected to Bartlett's test to evaluate the homogeneity of variance.

\section{RESULTS AND DISCUSSION}

\subsection{Growing season and phenological development}

The two experimental years were characterized by different meteorological conditions which strongly influenced crop growth and affected productivity (Fig. 1). In the first year, $361 \mathrm{~mm}$ of rain were recorded, with a regular distribution during the crop season (54\% in winter and $46 \%$ in the remaining period); during the second year, rainfall (446 $\mathrm{mm}$ ) was mainly during the winter (69\%); January and February were the most rainy months (90 and $150 \mathrm{~mm}$, respectively). The weather over both years was typically Mediterranean with the minimum temperature never below $0{ }^{\circ} \mathrm{C}$ and the maximum over $25{ }^{\circ} \mathrm{C}$ from late spring.

The organic and mineral fertilizations affected the crop cycle differently. In the first year, the stem extension phase was 14 days longer on average for fertilized plots compared with control (20 days) (Tab. I). As the developmental stage progressed, the differences between the fertilized plots and control decreased within a few days (maximum 6 at timing of anthesis). The full ripening stage was reached at 146 days after sowing for all the treatments. In the second year, treatments with the highest organic fertilization $\left(\mathrm{C}_{2}\right)$ and the control $\left(\mathrm{A}_{1}\right)$ had a significantly lower duration of booting (19 days in average), and the biological cycle (145 days on average) compared with the other treatments (27 and 152 days on average) (Tab. II). The organic and mineral fertilizations showed comparable results in the first year, whereas combining the highest dose of organic fertilization with the residual one produced an early end of the biological cycle due to premature senescence.

\subsection{Crop growth}

In the first year during tillering, the Leaf Area Index (LAI) was 0.6 , all treatments combined. There were significant differences in relation to fertilizations (organic or mineral) and doses applied at the heading stage: the highest LAI value corresponded to the treatment with the highest organic fertilization $(\mathrm{C})$, with a $32 \%$ increase compared with the lower dose (B) and mineral fertilization treatments (on average 2.2). Organic fertilization for two consecutive years resulted in a noticeable increase in LAI, except at the highest dose (Fig. 2). At heading, the repeated organic fertilization at the highest dose $\left(\mathrm{C}_{2}\right)$, the control and mineral fertilization showed the lowest LAI (0.6), while the remaining organic treatments showed increases ranging from three- $\left(B_{1}\right.$ and $\left.B_{2}\right)$ to five-fold $\left(C_{1}\right)$. 


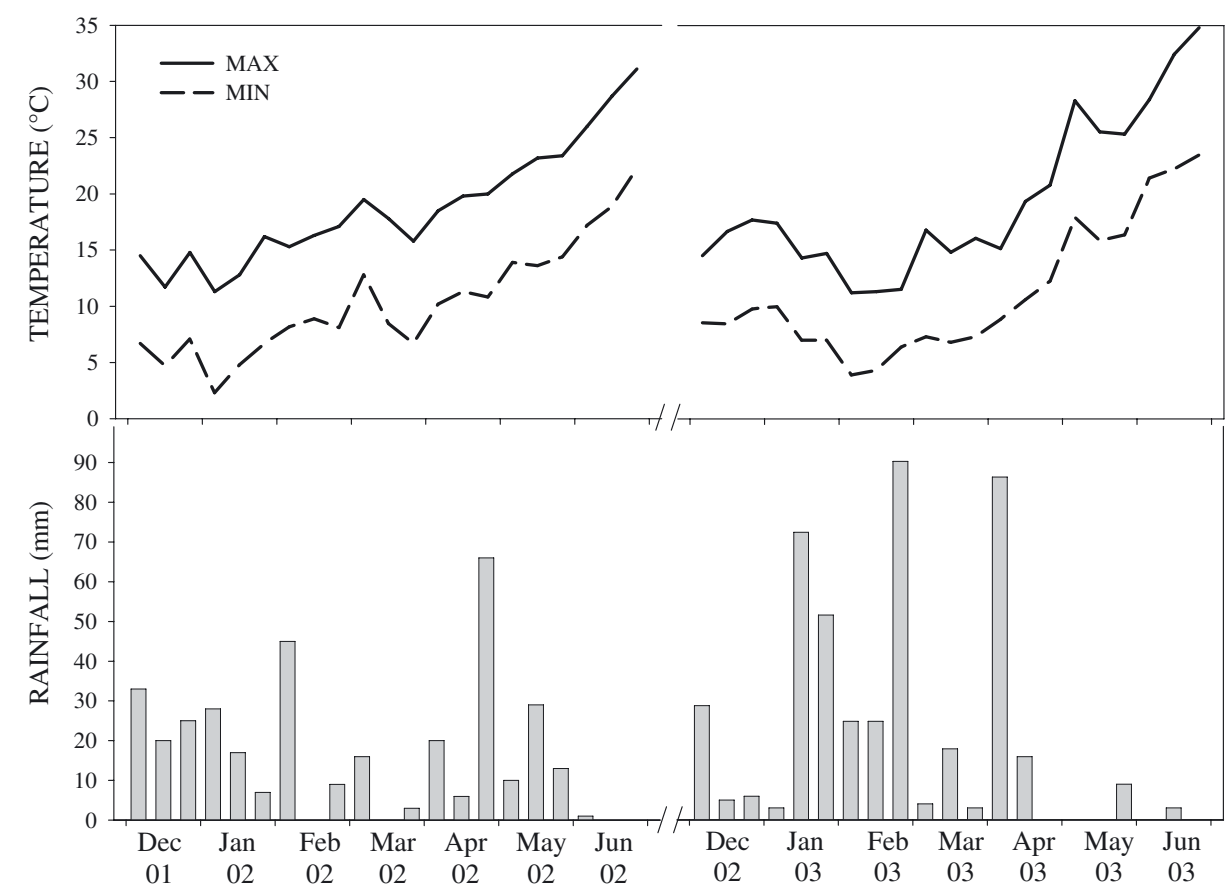

Figure 1. Meteorological conditions during the two-year trial: maximum temperature (MAX), minimum temperature (MIN) and rainfall.

Table I. Duration of the crop cycle and its main phenological phases in the 1 st year of trials in unconditioned soil (A), $4 \mathrm{~kg} \mathrm{~m}^{-2}$ orange waste (B), $8 \mathrm{~kg} \mathrm{~m}^{-2}$ orange waste (C) and mineral fertilization (D) treatments.

\begin{tabular}{lrrrrrc}
\hline & Tillering & $\begin{array}{c}\text { Stem } \\
\text { elongation }\end{array}$ & Booting & $\begin{array}{c}\text { Heading/ } \\
\text { Flowering }\end{array}$ & Ripening & $\begin{array}{c}\text { Biological } \\
\text { cycle }\end{array}$ \\
\cline { 2 - 7 } & \multicolumn{6}{c}{ days } \\
\hline $\mathrm{A}$ & $41 \mathrm{a}$ & $20 \mathrm{~b}$ & $11 \mathrm{a}$ & $16 \mathrm{a}$ & 33 & 146 \\
$\mathrm{~B}$ & $32 \mathrm{~b}$ & $36 \mathrm{a}$ & $7 \mathrm{~b}$ & $10 \mathrm{~b}$ & 36 & 146 \\
$\mathrm{C}$ & $36 \mathrm{~b}$ & $31 \mathrm{a}$ & $8 \mathrm{~b}$ & $10 \mathrm{~b}$ & 36 & 146 \\
$\mathrm{D}$ & $34 \mathrm{~b}$ & $35 \mathrm{a}$ & $6 \mathrm{~b}$ & $10 \mathrm{~b}$ & 36 & 146 \\
\hline
\end{tabular}

In each column values followed by different lower-case letters are significantly different at $P \leq 0.05$ using the Least Significant Difference test.

The above-ground biomass recorded during the first year was positively affected by both organic and inorganic fertilization, with significant differences between these treatments until heading (Fig. 3). At this stage, the highest organic fertilization determined a significant increase in dry weight of $28 \%$, compared with the lower dose or with mineral fertilization (729 $\mathrm{g} \mathrm{m}^{-2}$, on average). At the milk-ripening stage, no differences were detected among fertilized treatments.

In the second year, the control $\left(\mathrm{A}_{1}\right)$, the repeated organic fertilization at the highest dose $\left(C_{2}\right)$ and the mineral fertilizer $\left(D_{1}\right)$ showed the lowest values $\left(222 \mathrm{~g} \mathrm{~m}^{-2} \mathrm{~d}\right.$.w. on average) at heading, whereas the remaining organic treatments showed increases of $2.7\left(B_{1}\right.$ and $\left.B_{2}\right)$ and 4 times $\left(C_{1}\right)$. At the milk-ripening stage, the repeated highest organic fertilization showed values significantly lower than the mineral one.
Table II. Duration of the crop cycle and its main phenological phases in the 2nd year of trials in control $\left(\mathrm{A}_{1}=\mathrm{A}+0\right), \mathrm{B}_{1}\left(\mathrm{~B}+0 \mathrm{~kg} \mathrm{~m}^{-2}\right)$, $\mathrm{B}_{2}\left(\mathrm{~B}+4 \mathrm{~kg} \mathrm{~m}^{-2}\right), \mathrm{C}_{1}\left(\mathrm{C}+0 \mathrm{~kg} \mathrm{~m}^{-2}\right), \mathrm{C}_{2}\left(\mathrm{C}+8 \mathrm{~kg} \mathrm{~m}^{-2}\right)$ and $\mathrm{D}_{1}(\mathrm{D}$ $\left.+80 \mathrm{~kg} \mathrm{ha}^{-1} \mathrm{~N}\right)$ treatments.

\begin{tabular}{lcccccc}
\hline & Tillering & $\begin{array}{c}\text { Stem } \\
\text { elongation }\end{array}$ & Booting & $\begin{array}{c}\text { Heading/ } \\
\text { Flowering }\end{array}$ & Ripening & $\begin{array}{c}\text { Biological } \\
\text { cycle }\end{array}$ \\
\cline { 2 - 7 } & \multicolumn{6}{c}{ days } \\
\hline $\mathrm{A}_{1}$ & 20 & $40 \mathrm{a}$ & $17 \mathrm{~b}$ & 11 & 33 & $146 \mathrm{~b}$ \\
$\mathrm{~B}_{1}$ & 22 & $35 \mathrm{~b}$ & $28 \mathrm{a}$ & 10 & 33 & $153 \mathrm{a}$ \\
$\mathrm{B}_{2}$ & 23 & $34 \mathrm{~b}$ & $28 \mathrm{a}$ & 10 & 33 & $153 \mathrm{a}$ \\
$\mathrm{C}_{1}$ & 20 & $35 \mathrm{~b}$ & $25 \mathrm{a}$ & 11 & 33 & $150 \mathrm{a}$ \\
$\mathrm{C}_{2}$ & 24 & $33 \mathrm{~b}$ & $20 \mathrm{~b}$ & 10 & 33 & $144 \mathrm{~b}$ \\
$\mathrm{D}_{1}$ & 24 & $36 \mathrm{~b}$ & $25 \mathrm{a}$ & 10 & 33 & $153 \mathrm{a}$ \\
\hline
\end{tabular}

In each column values followed by different lower-case letters are significantly different at $P \leq 0.05$ using the Least Significant Difference test.

LAI and above-ground biomass show that organic fertilization promotes plant vigor much more than mineral fertilization, except at the maximum dose. The Crop Growth Rate index validated that organic fertilization stimulated crop growth, with the exception of the highest dose applied for two years (Fig. 4). In the first year, up to heading, organic fertilization almost doubled the growth rate compared with the control and mineral fertilization $\left(5.8 \mathrm{~g} \mathrm{~m}^{-2} \mathrm{~d}^{-1}\right.$ on average). Subsequently, there were few differences between treatments. Taking direct and residual effects into account, the highest organic dose applied the previous year $\left(\mathrm{C}_{1}\right)$ produced the highest growth rate $\left(14.6 \mathrm{~g} \mathrm{~m}^{-2} \mathrm{~d}^{-1}\right)$, with a $54 \%$ increase compared with $\mathrm{B}_{1}$ and $\mathrm{B}_{2}\left(9.45 \mathrm{~g} \mathrm{~m}^{-2} \mathrm{~d}^{-1}\right.$ on average). In the 


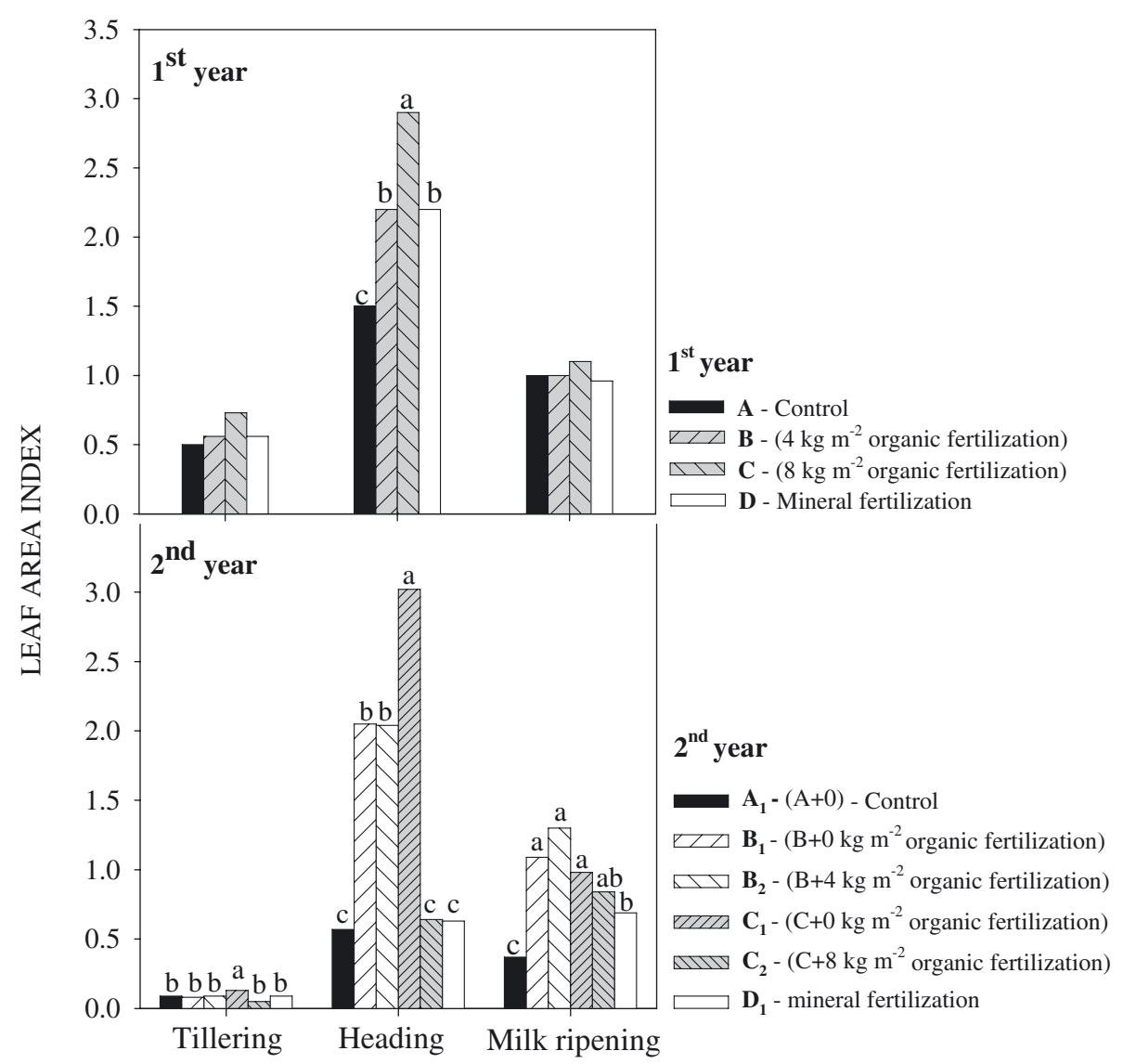

Figure 2. Leaf Area Index in the two-year trial. A: unconditioned soil control; B: $4 \mathrm{~kg} \mathrm{~m}^{-2}$ orange waste; $\mathrm{C}: 8 \mathrm{~kg} \mathrm{~m}{ }^{-2}$ orange waste; D: mineral fertilization. $A_{1}$ : unconditioned soil $(A+0) ; B_{1}: B+0 \mathrm{~kg} \mathrm{~m}^{-2} ; B_{2}: B+4 \mathrm{~kg} \mathrm{~m}^{-2} ; C_{1}: C+0 \mathrm{~kg} \mathrm{~m}^{-2} ; C_{2}: B+8 \mathrm{~kg} \mathrm{~m}^{-2} ; \mathrm{D}_{1}:$ repeated mineral fertilization $\left(\mathrm{D}+80 \mathrm{~kg} \mathrm{ha}^{-1} \mathrm{~N}\right)$. For each sampling, different lower-case letters indicate significant differences at $P \leq 0.05$ using the Least Significant Difference test.

following stage, the control confirmed the lowest growth rate $\left(8.84 \mathrm{~g} \mathrm{~m}^{-2} \mathrm{~d}^{-1}\right)$, while the lower organic dose applied in one or both years $\left(\mathrm{B}_{1}, \mathrm{~B}_{2}\right)$ and mineral fertilization $\left(\mathrm{D}_{1}\right)$ produced the highest value $\left(20.0 \mathrm{~g} \mathrm{~m}^{-2} \mathrm{~d}^{-1}\right.$ on average). Increased plant vigor by orange waste organic fertilization was also observed in wheat (Belligno et al., 2005), in lettuce (Correia Guerrero et al., 1995) and in sunflower (Abbate et al., 2008).

\subsection{Yield and its components}

In the first year, the fertilizer treatments produced a twofold greater grain yield and a 1.5 times greater Harvest Index compared with the control (Tab. III). The analysis of yield components clearly showed that the lower control yield was due to both fewer kernels per head and lower seed weight.

Similar results were produced in the second year, when the highest dose of organic fertilizer applied for two consecutive years and the control exhibited a 50\% decrease in grain yield compared with the other treatments (Tab. IV). The analysis of yield components showed that the lowest yield $\left(2 \mathrm{tha}^{-1}\right)$ was mainly due to low seed weight (25g per 1000 seeds) and low plant density (179 plants $\mathrm{m}^{-2}$ ) in $\mathrm{C}_{2}$, and to lower kernel number (11.9) in the control. Plant density in the second year of trials proved much lower than planned, with decreases ranging from 20 to $55 \%\left(\mathrm{C}_{2}\right)$, due to high rainfall during the seedling stage (January). The organic treatments accounted for the lowest values of the Harvest Index, showing that higher biomass did not proportionally increase yield.

To evaluate the orange waste dose sustainable from an agronomic perspective, and excluding the treatment which depressed growth and yield, we compared the Agronomic Efficiency Index values for organic fertilization. In both years, it showed decreasing values with increasing dose supplied: $58(\mathrm{~B}), 37(\mathrm{C}), 35.6\left(\mathrm{~B}_{1}\right), 28.4\left(\mathrm{C}_{1}\right)$ and $22.4\left(\mathrm{~B}_{2}\right) \mathrm{kg}$ per ton of kernels. The direct and residual effects of the lower doses (B and $\mathrm{B}_{1}$ ) produced the highest agronomic efficiency. However, the $8 \mathrm{~kg}$ dose applied only in the first year showed slightly higher values than the $4 \mathrm{~kg}$ dose applied for two consecutive years.

These results agree with Belligno et al. (2005), who stated that increasing doses of dried industrial orange waste from 3 to $9 \mathrm{~kg} \mathrm{~m}^{-2}$ had a positive influence on wheat growth, but the production was enhanced by the lower dose. Abbate et al. (2008) 


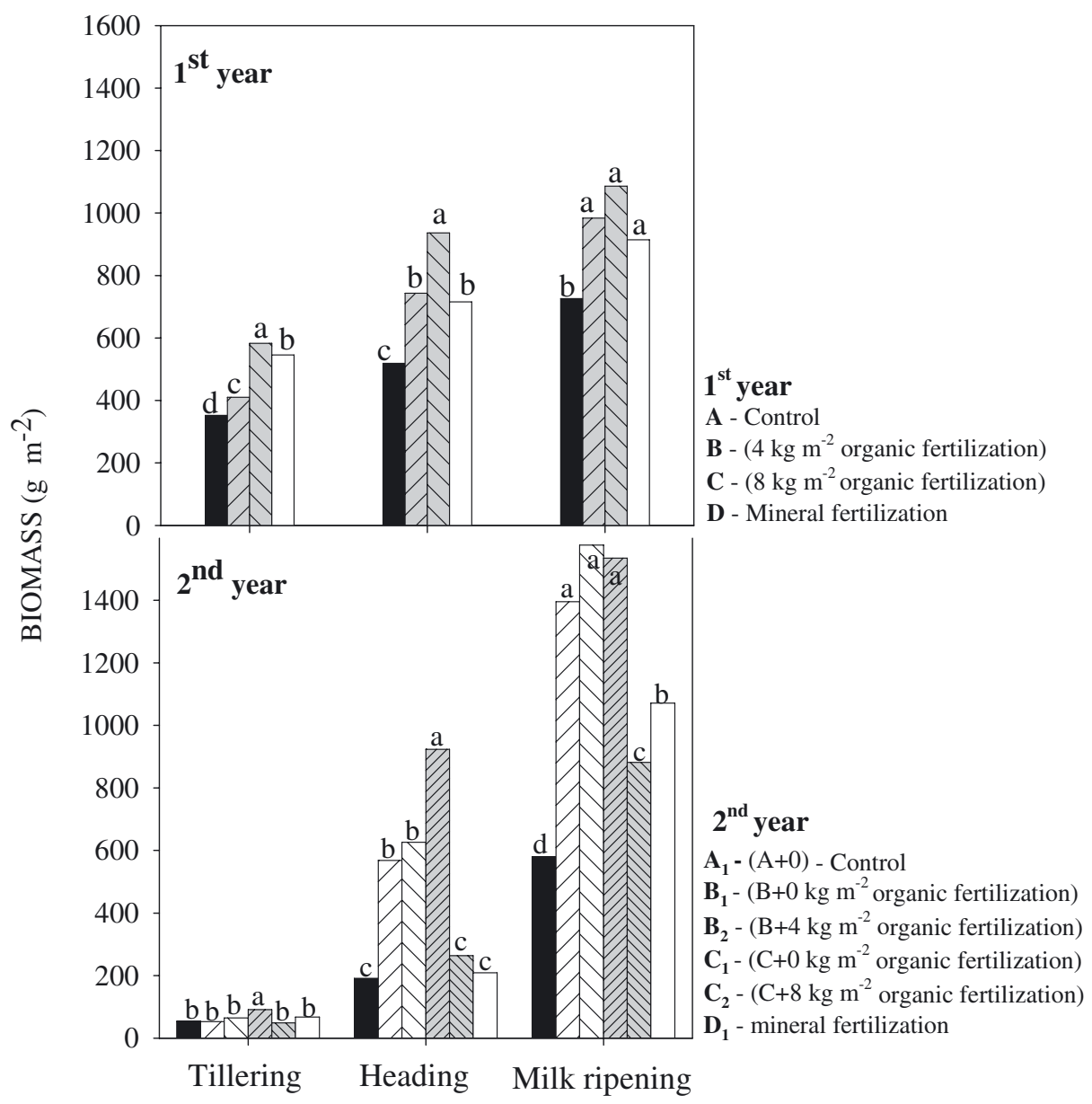

Figure 3. Above-ground biomass in the two-year trial. A: unconditioned soil control; $\mathrm{B}: 4 \mathrm{~kg} \mathrm{~m}^{-2}$ orange waste; $\mathrm{C}: 8 \mathrm{~kg} \mathrm{~m} \mathrm{~m}^{-2}$ orange waste; $\mathrm{D}$ : mineral fertilization. $A_{1}$ : unconditioned soil $(A+0) ; B_{1}: B+0 \mathrm{~kg} \mathrm{~m}^{-2} ; B_{2}: B+4 \mathrm{~kg} \mathrm{~m}^{-2} ; C_{1}: C+0 \mathrm{~kg} \mathrm{~m}^{-2} ; C_{2}: C+8 \mathrm{~kg} \mathrm{~m}^{-2} ; \mathrm{D}_{1}:$ repeated mineral fertilization $\left(\mathrm{D}+80 \mathrm{~kg} \mathrm{ha}^{-1} \mathrm{~N}\right)$. For each sampling, different lower-case letters indicate significant differences at $P \leq 0.05$ using the Least Significant Difference test.

Table III. Grain yield and its characteristics in the 1 st year of trials in control (A), $4 \mathrm{~kg} \mathrm{~m}^{-2}$ orange waste (B), $8 \mathrm{~kg} \mathrm{~m}^{-2}$ orange waste (C) and mineral fertilization (D) treatments.

\begin{tabular}{ccccccc}
\hline & $\begin{array}{c}\text { Plants at } \\
\text { sowing } \\
\left(\mathrm{n}^{\circ} \mathrm{m}^{-2}\right)\end{array}$ & $\begin{array}{c}\text { Heads } \\
\left(\mathrm{n}^{\circ} \mathrm{m}^{-2}\right)\end{array}$ & $\begin{array}{c}\text { Kernels } \\
\text { per head } \\
\left(\mathrm{n}^{\circ}\right)\end{array}$ & $\begin{array}{c}1000 \mathrm{seed} \\
\text { weight } \\
(\mathrm{g})\end{array}$ & $\begin{array}{c}\text { Yield } \\
(\mathrm{t} / \mathrm{ha})\end{array}$ & H.I. \\
\hline $\mathrm{A}$ & 387 & $443 \mathrm{c}$ & $14.3 \mathrm{~b}$ & $37.8 \mathrm{c}$ & $2.39 \mathrm{~b}$ & $0.33 \mathrm{~b}$ \\
$\mathrm{~B}$ & 412 & $471 \mathrm{bc}$ & $23.0 \mathrm{a}$ & $46.0 \mathrm{a}$ & $4.98 \mathrm{a}$ & $0.51 \mathrm{a}$ \\
$\mathrm{C}$ & 413 & $487 \mathrm{ab}$ & $23.0 \mathrm{a}$ & $47.8 \mathrm{a}$ & $5.35 \mathrm{a}$ & $0.49 \mathrm{a}$ \\
$\mathrm{D}$ & 426 & $514 \mathrm{a}$ & $22.0 \mathrm{a}$ & $43.6 \mathrm{~b}$ & $4.94 \mathrm{a}$ & $0.54 \mathrm{a}$ \\
\hline
\end{tabular}

H.I. = Harvest Index. In each column values followed by different lowercase letters are significantly different at $P \leq 0.05$ using the Least Significant Difference test.

reported favorable effects of orange waste organic fertilization on sunflower growth and production up to the highest dose $\left(9 \mathrm{~kg} \mathrm{ha}^{-1}\right)$. This difference could be ascribed to the lower tolerance of wheat to abundant organic matter in the soil.
Some reports (Mader et al. 2002; Ryan et al. 2004; Gopinath et al., 2008) found that organic wheat yields were $17-84 \%$ lower than conventional yields, due to the less readily-available nutrients in the initial years of transition, as nutrient cycling processes in first-year organic systems change from inorganic $\mathrm{N}$ fertilization to organic amendments (Reider et al., 2000), and slower release rates of organic materials (MacRae et al., 1993). Our results demonstrate that orange waste organic fertilization can be efficaciously applied to wheat in organic farming, without reducing yield, which frequently occurs in transition years.

\section{CONCLUSION}

Organic fertilization with orange waste leads to both direct and indirect effects on durum wheat growth and productivity. In general, organic fertilization stimulated crop growth compared with mineral fertilization, but when applied for two consecutive years at the maximum dose, it severely impaired 


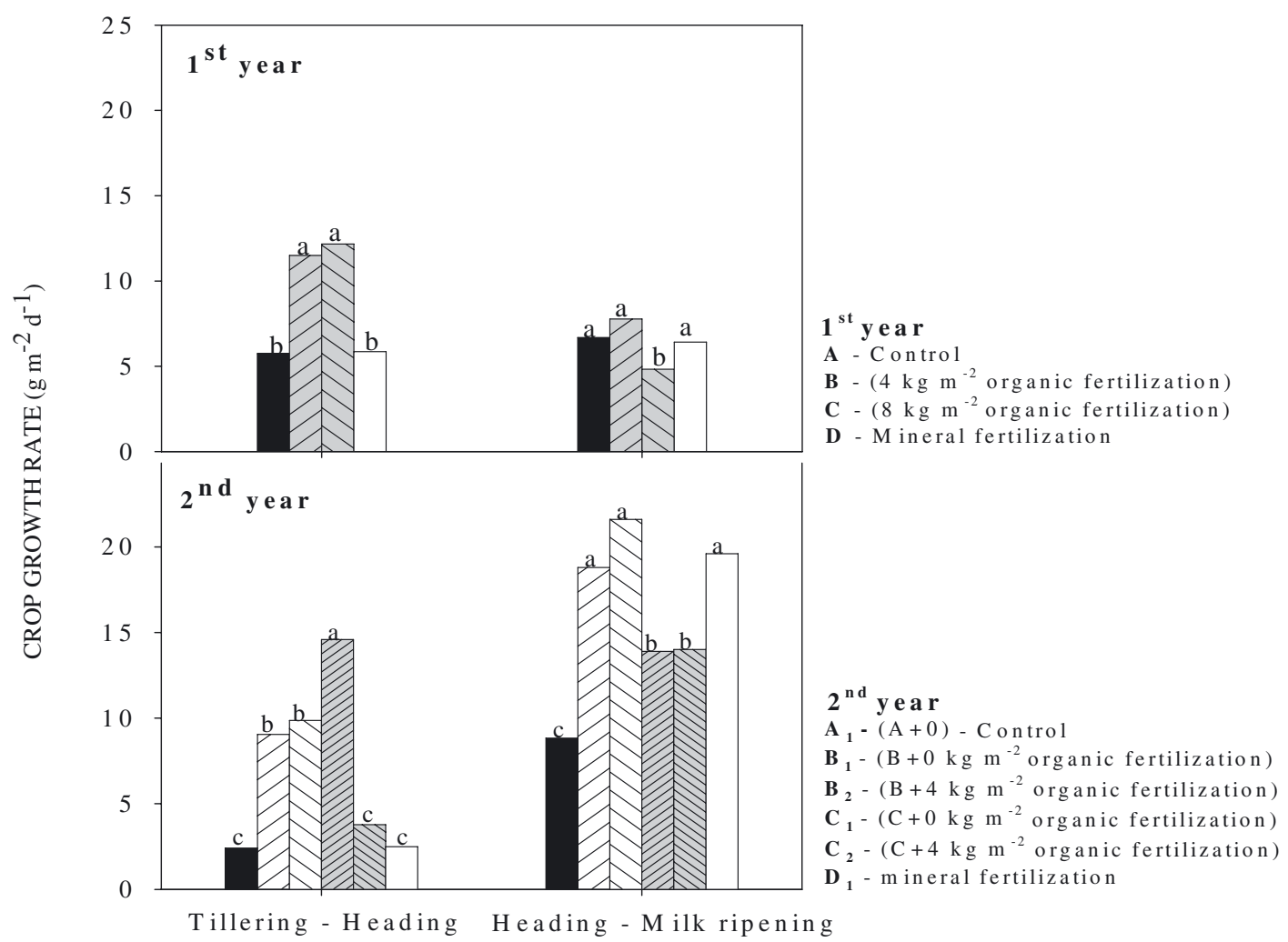

Figure 4. Crop growth rate in the two-year trial. A: unconditioned soil control; B: $4 \mathrm{~kg} \mathrm{~m}^{-2}$ orange waste; C: $8 \mathrm{~kg} \mathrm{~m}{ }^{-2}$ orange waste; D: mineral fertilization. $\mathrm{A}_{1}$ : unconditioned soil $(\mathrm{A}+0) ; \mathrm{B}_{1}: \mathrm{B}+0 \mathrm{~kg} \mathrm{~m}^{-2} ; \mathrm{B}_{2}: \mathrm{B}+4 \mathrm{~kg} \mathrm{~m}^{-2} ; \mathrm{C}_{1}: \mathrm{C}+0 \mathrm{~kg} \mathrm{~m}^{-2} ; \mathrm{C}_{2}: \mathrm{C}+8 \mathrm{~kg} \mathrm{~m}^{-2} ;{ }_{1}: \mathrm{repeated} \mathrm{mineral}$ fertilization $\left(\mathrm{D}+80 \mathrm{~kg} \mathrm{ha}^{-1} \mathrm{~N}\right)$. For each sampling, different lower-case letters indicate significant differences at $P \leq 0.05$ using the Least Significant Difference test.

Table IV. Grain yield and its characteristics in the second year of trials in control $\left(\mathrm{A}_{1}=\mathrm{A}+0\right), \mathrm{B}_{1}\left(\mathrm{~B}+0 \mathrm{~kg} \mathrm{~m}^{-2}\right), \mathrm{B}_{2}\left(\mathrm{~B}+4 \mathrm{~kg} \mathrm{~m}^{-2}\right)$, $\mathrm{C}_{1}\left(\mathrm{C}+0 \mathrm{~kg} \mathrm{~m}^{-2}\right), \mathrm{C}_{2}\left(\mathrm{C}+8 \mathrm{~kg} \mathrm{~m}^{-2}\right)$ and $\mathrm{D}_{1}\left(\mathrm{D}+80 \mathrm{~kg} \mathrm{ha}^{-1} \mathrm{~N}\right)$ treatments.

\begin{tabular}{lcccccc}
\hline & $\begin{array}{c}\text { Plants at } \\
\text { sowing } \\
\left(\mathrm{n}^{\circ} \mathrm{m}^{-2}\right)\end{array}$ & $\begin{array}{c}\text { Heads } \\
\left(\mathrm{n}^{\circ} \mathrm{m}^{-2}\right)\end{array}$ & $\begin{array}{c}\text { Kernels } \\
\text { per head } \\
\left(\mathrm{n}^{\circ}\right)\end{array}$ & $\begin{array}{c}1000 \mathrm{seed} \\
\text { weight } \\
(\mathrm{g})\end{array}$ & $\begin{array}{c}\text { Yield } \\
(\mathrm{t} / \mathrm{ha})\end{array}$ & H.I. \\
\hline $\mathrm{A}_{1}$ & $315 \mathrm{a}$ & 372 & $11.9 \mathrm{c}$ & $47.8 \mathrm{a}$ & $2.12 \mathrm{~b}$ & $0.37 \mathrm{a}$ \\
$\mathrm{B}_{1}$ & $251 \mathrm{~b}$ & 353 & $23.4 \mathrm{a}$ & $45.0 \mathrm{a}$ & $3.72 \mathrm{a}$ & $0.30 \mathrm{~b}$ \\
$\mathrm{~B}_{2}$ & $337 \mathrm{a}$ & 391 & $25.0 \mathrm{a}$ & $40.4 \mathrm{~b}$ & $3.91 \mathrm{a}$ & $0.25 \mathrm{c}$ \\
$\mathrm{C}_{1}$ & $310 \mathrm{a}$ & 305 & $24.2 \mathrm{a}$ & $46.0 \mathrm{a}$ & $3.40 \mathrm{a}$ & $0.23 \mathrm{c}$ \\
$\mathrm{C}_{2}$ & $179 \mathrm{c}$ & 344 & $20.9 \mathrm{~b}$ & $25.1 \mathrm{c}$ & $1.80 \mathrm{~b}$ & $0.20 \mathrm{c}$ \\
$\mathrm{D}_{1}$ & $271 \mathrm{~b}$ & 363 & $19.8 \mathrm{~b}$ & $48.7 \mathrm{a}$ & $3.50 \mathrm{a}$ & $0.33 \mathrm{~b}$ \\
\hline
\end{tabular}

H.I. = Harvest Index. In each column values followed by different lowercase letters are significantly different at $P \leq 0.05$ using the Least Significant Difference test.

crop establishment, growth rate and production. The direct use of this fertilizer in agriculture could be a low-cost technology to complete the biogeochemical cycle of nutritional elements for wheat in organic or conventional farming, and could also be a valuable opportunity to reduce the environmental and economic costs related to its disposal.

\section{REFERENCES}

Abbate C., Tuttobene R., Avola G., Gennari M. (2008). The effect of citrus pulp amendment on sunflower production and the dissipation of the erbicide aclonifen, Ital. J. Agron. 3, 341-347.

Belligno A., Di Leo M., Marchese M., Tuttobene R. (2005) Effects of "industrial orange wastes" on soil characteristics and on growth and production of durum wheat (Triticum durum Desf.), Agron. Sustain. Dev. 25, 129-135.

Braddock R.J. (1999) Handbook of Citrus By-Products and Processing Technology, John Wiley \& Sons, Inc., New York, NY.

Correia Guerrero C., Carrasco de Brito J., Lapa N., Santos Oliveira J.F. (1995) Re-use of industrial orange wastes as organic fertilizers, Bioresource Technol. 53, 43-51.

Fisichella A. (2004) Pastazzo d'agrumi - Residuato dai processi di lavorazione delle industrie di trasformazione - Il trattamento anaerobico, Consulting 6, 18-22.

Gentry T.S., Braddock R.J., Miller W.M., Sims C.A., Gregory J.F. (2001) Volatile organic compounds from citrus feed mill emissions, J. Food Process Eng. 24, 1-15.

Gopinath K.A., Saha S., Mina B.L., Pande H., Kundu S., Gupta H.S. (2008) Influence of organic amendments on growth, yield and quality of wheat and on soil properties during transition to organic production, Nutr. Cycl. Agroecosys. 82, 51-60. 
Ingram L.O., Doran J.B. (1995) Conversion of Cellulosic Materials to Ethanol, FEMS Microbiol. Rev. 16, 235-241.

Intrigliolo F., Allegra M., Torrisi B. (2005) Application of organic fertilisers in orange orchard in southern Italy, Geophys. Res. Abstract 7, 286.

MacRae R.J., Hill S.B., Mehuys G.R., Henning J. (1993) Farm-scale agronomic and economic conversion from conventional to sustainable agriculture, Adv. Agron. 43, 155-198.

Mader P., Fliebach A., Dubois D. Gunst L., Fried P., Niggli U. (2002) Soil fertility and biodiversity in organic farming, Science 296,16941697.

Merillot J.M. (1998) Management strategies related to legislature, economics, agronomic and environmental impact of organic wastes, in: Martinez J., Maudet M. (Eds.), Proceedings of the 8th International Conference on Management Strategies for Organic Waste Use in Agriculture, Cemagref, France, May 26-29, pp. 15-24.
Oluremi O.I.A., Ngi J., Andrew I.A. (2007) Phytonutrients in citrus fruit peel meal and nutritional implication for livestock production, Livest. Res. Rural Dev. 19, 89.

Reider C., Herdman W., Drinkwater L.E., Janke R. (2000) Yields and nutrient budgets under composts, raw dairy manure and mineral fertilizer, Compost Sci. Util. 8, 328-339.

Ryan M.H., Derrick J.W., Dann P.R. (2004) Grain mineral concentrations and yield of wheat grown under organic and conventional management, J. Sci. Food Agr. 84, 207-216.

Van Heerden I., Cronjè C., Swart S.H., Kotzè J.M. (2002) Microbial, chemical and physical aspects of citrus waste composting, Bioresource Technol. 81, 71-76.

Wagner J.J., Lusby K.S., Horn G.W. (1983) Condensed molasses solubles, corn steep liquor and fermented ammonia condensed whey as protein sources for beef cattle grazing dormant native range, J. Anim. Sci. 57, 542. 